Adzo Dzifa KoKUTSE ${ }^{1}$

Afiwa Dzigbodi AKPENË ${ }^{1}$

Olivier MONTEUUIS ${ }^{2}$

Arcadius AKossou ${ }^{3}$

Patrick LANGBOUR ${ }^{4}$

Daniel GUIBAL ${ }^{4}$

Mario F. TOMAZELLO 5

Edjidomélé GBADOE ${ }^{6}$

Gilles CHAIX ${ }^{2,5}$

Kouami KoкоU ${ }^{1}$

${ }^{1}$ Université de Lomé

Faculty of Sciences

Laboratory of Botanic

and Plant Ecology

BP 1515, Lomé

Togo

${ }^{2}$ Cirad

UMR AGAP

Avenue Agropolis

34398 Montpellier Cedex 5

France

${ }^{3}$ Université de Parakou

Faculty of Agronomy

Parakou

Republic of Benin

${ }^{4}$ Cirad

UR BIOWOOEB

73 rue Jean-François Breton 34398 Montpellier Cedex 5 France

${ }^{5}$ Universidade de São Paulo ESALQ

Departamento de Ciências Florestais

Avenida Pádua Dias 11

Caixa Postal 9

São Paulo

Brazil

${ }^{6}$ Togolese forest and logging development agency

ODEF

Lomé

Togo

\section{Selection of Plus trees for genetically improved teak varieties produced in Benin and Togo}

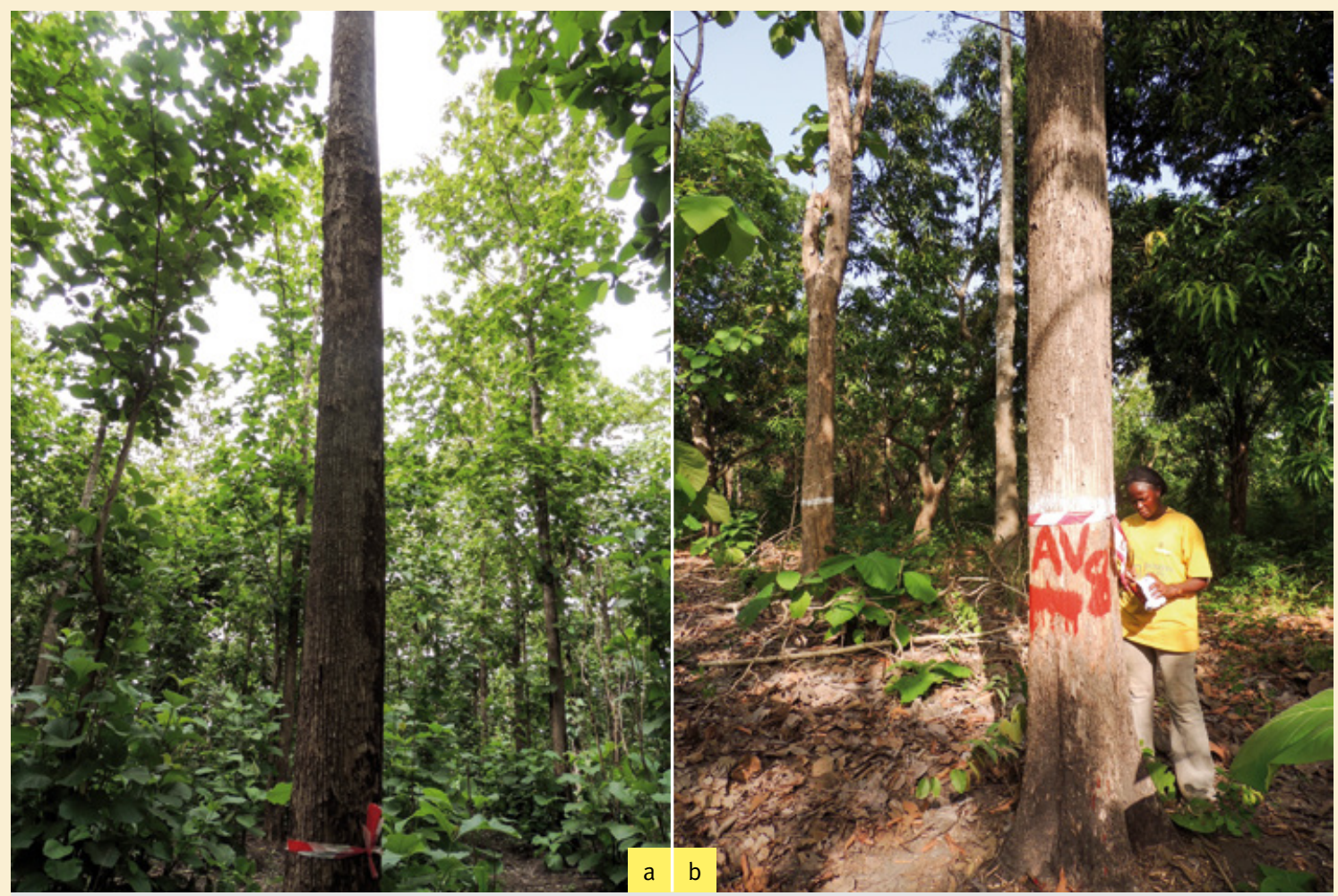

Photo 1.

Morphological aspect of Teak Candidate Plus Tree

in Koto forest (a: Benin) and in Avetonou forest (b: Togo). 


\section{RÉSUMÉ}

\section{SÉLECTION D’ARBRES « PLUS » POUR LA PRODUCTION DE VARIÉTÉS DE TECK GÉNÉTIQUEMENT AMÉLIORÉES AU BÉNIN ET AU TOGO}

Cette étude vise la sélection d'arbres "plus» sur la base des caractères dendrométriques et des propriétés du bois dans des plantations de teck au Bénin et au Togo. La croissance de 569 arbres dans 5 forêts au Togo et 90 arbres dans 3 forêts au Bénin a été évaluée en mesurant le diamètre à hauteur de poitrine, la hauteur totale et la hauteur du fût. Les propriétés suivantes du bois ont été évaluées et prises en compte pour la sélection finale d'arbres "plus»: densité, pourcentage de bois de cœur et couleur. La durabilité naturelle du bois de cœur, le point de saturation des fibres, le module d'élasticité et les retraits ont été évalués sur la base de modèles spectroscopiques dans le proche infrarouge, préalablement construits. Nos résultats montrent qu'au Togo la variabilité inter-arbres en forêt est assez forte pour l'accroissement annuel en hauteur $(0,81 \pm 0,27 \mathrm{~m})$, en circonférence $(2,95 \pm 1,02 \mathrm{~cm})$ et en hauteur des fûts $(10,64 \pm 3,51 \mathrm{~m})$. Au Bénin, si les performances dendrométriques des arbres ne varient pas de façon significative entre les forêts, pour la hauteur des fûts $(10,99 \pm 3,80 \mathrm{~m})$, les valeurs du coefficient de variation sont plus élevées (40\%) pour la forêt de Koto. Prenant en compte les propriétés du bois, la sélection finale multicritères montre que les peuplements d'Avétonou et de Tchorogo au Togo constituent un groupe homogène affichant les plus fortes valeurs pour la densité du bois et le pourcentage de bois de cœur. Les arbres des forêts de Haho-Baloe et Eto ont des valeurs plus faibles pour la durabilité naturelle, le module d'élasticité, le pourcentage de bois de cœur et la densité du bois. Au Bénin, les arbres de la forêt d'Agrimey ont une densité plus élevée mais les valeurs pour le point de saturation des fibres, la durabilité naturelle et le retrait du bois sont similaires pour les trois forêts. La variabilité des performances dendrométriques et de la qualité du bois des arbres-candidat nous ont permis de sélectionner 33 arbres « plus ».

Mots-clés : peuplements de teck, arbre "plus », sélection, croissance, propriétés du bois, Bénin, Togo.

\section{ABSTRACT}

\section{SELECTION OF PLUS TREES FOR GENETICALLY IMPROVED TEAK VARIETIES PRODUCED IN BENIN AND TOGO}

The aim of this study is to select "Plus Trees" based on dendrometric characteristics and wood properties in teak plantations in Benin and Togo. For this purpose, growth performance was assessed in 569 trees in 5 forests in Togo and 90 trees in 3 forests in Benin, based on diameter at breast height, total height and bole height measurements. Wood properties - density, percentage of heartwood and colour - were also measured for the final selection of Plus trees. Heartwood natural durability, fibre saturation point, modulus of elasticity and shrinkage were assessed against previous near infrared spectroscopy models. The results showed that in Togo, inter-tree variability in the forests was relatively high for Annual Height $(0.81 \pm 0.27 \mathrm{~m})$ and Annual Circumference Increments $(2.95 \pm 1.02 \mathrm{~cm})$ and for bole heights $(10.64 \pm 3.51 \mathrm{~m})$. In Benin, while the dendrometric performance of the trees did not vary significantly between the forests, the coefficient of variation values were higher ( $40 \%)$ for bole heights $(10.99 \pm 3.80 \mathrm{~m})$ in Koto forest. The final multi-criteria selection including wood properties showed that the Avetonou and Tchorogo tree populations in Togo make up a homogenous group with the highest values for wood density and heartwood percentage. The trees in Haho-Baloe and Eto forests had lower natural durability and modulus of elasticity, a lower percentage of heartwood and lower wood density. In Benin, the Agrimey forest trees had a higher wood density but the 3 forests were similar in terms of fibre saturation point, natural durability and shrinkage. Based on the variability of dendrometric performance and wood quality of the candidate trees, we were able to select 33 Plus trees.

Keywords: Teak populations, Plus Tree, selection, growth performance, wood properties, Benin, Togo.

\author{
A. Akossou, P. Lang bour, D. Guibal, \\ M. F. Tomazello, E. Gbadoe, G. Chaix, \\ K. KоKOU
}

RESUMEN

\section{SELECCIÓN DE ÁRBOLES PLUS PARA LA PRODUCCIÓN DE VARIEDADES DE TECA GENÉTICAMENTE MEJORADAS EN BENÍN Y TOGO}

El objetivo de este estudio es seleccionar árboles plus basándose en características dendrométricas y propiedades de la madera en plantaciones de teca de Benín y Togo. Se evaluó el crecimiento de 569 árboles en 5 bosques de Togo y 90 árboles en 3 bosques de Benín midiendo el diámetro a la altura del pecho, altura total y altura de fuste. Para la selección final de árboles plus, se evaluaron y tuvieron en cuenta las siguientes propiedades de la madera: densidad, porcentaje de duramen y color. La durabilidad natural del duramen, el punto de saturación de las fibras, el módulo de elasticidad y la contracción se evaluaron usando modelos anteriores de espectrometría del infrarrojo cercano. Nuestros resultados muestran que, en Togo, la variabilidad entre árboles en los bosques es relativamente alta en la altura anual $(0,81 \pm 0,27 \mathrm{~m})$, el incremento anual de la circunferencia $(2,95 \pm 1,02 \mathrm{~cm})$ y la altura de fuste $(10,64 \pm 3,51 \mathrm{~m})$. En Benín, aunque el desempeño dendrométrico de los árboles no varía de modo significativo entre los bosques, los valores del coeficiente de variación son más altos (40\%) en el bosque de Koto. La selección final a partir de criterios múltiples, que integran las propiedades de la madera, muestra que las poblaciones de árboles de Avétonou y Tchorogo en Togo conforman un grupo homogéneo que presenta los valores más altos de densidad de la madera y porcentaje de duramen. Los árboles de los bosques de Haho-Baloe y Eto presentan valores más bajos de durabilidad natural, módulo de elasticidad, porcentaje de duramen y densidad de la madera. En Benín, los árboles del bosque de Agrimey presentan una densidad superior, pero el punto de saturación de las fibras, la durabilidad natural y la contracción de la madera son similares en los 3 bosques. Basándonos en la variabilidad del desempeño dendrométrico y la calidad de la madera de los árboles candidatos, pudimos seleccionar 33 árboles plus.

Palabras clave: poblaciones de teca, árbol plus, selección, crecimiento, propiedades de la madera, Benín, Togo. 


\section{Introduction}

To meet the growing demand for timber and wood services, most West African countries have implemented fast-growing policies oriented to exotic forest species plantations. In Togo and Benin, teak (Tectona grandis L.f.) is the most used species in terms of planted surfaces, due to high consumers' interest for its wood and teak tolerance to bush fire. Currently, the forest surfaces extend to about 50,000 ha (MERF/FAO, 2011) in Togo, with teak covering more than 17,000 hectares in the Benin State forests (Ganglo et al., 1999; Ganglo and Foucault, 2006). These teak plantations, which belong to the State or to smallholders, are the most important sources of timber supply in both countries. Nevertheless, the local timber market faces huge issues, particularly in Togo for many reasons: 1) Plantations are based mainly on seed spreading. This generative propagation for this insect-pollinated species, mainly allogame, does not ensure the transfer of major economic characters which are not under additive control (Monteuuis et al., 2007). 2) Current plantations have presumably very low productivity due to consangunity, as original germplasm has not been enriched by new genetic materials. Moreover, the genetic material, initially selected for rotations of 40 to 60 years, shows a significant reduction in genetic gain. It is also less and less adapted to the local market's growing demand for wood, with 20-25 years rotation. In addition tree stands can no longer reach maturity in age to get good heartwood quality, in terms of color definition. It was established that the proportion of heartwood which is an important factor for teak wood quality increased with tree age (Bhat, 1995; Kokutse et al., 2004) and during the process of heartwood formation, some chemical processes take place, which improve durability and change the colour of the wood (Datta and Kumar, 1987 ; Higuchi 1997; Moya and Alvarado-Calvo, 2012; Moya et al., 2014). Indeed there is an increasing demand of the Togo dark teakwood on the market (Kokutse et al., 2006). 3) In West Africa, the teak flowering may occurs earlier (Béhaghel, 1999; Azankpan et al., 2009), around 2-3 years after planting depending on the genotype (Tondjo et al., 2014). This leads to a premature forking and short logs, with therefore, a lower commercial value.

In order to improve the wood production, new selected genetic origins, according to the quality of their bole and absence of wood defects, were introduced in both countries. In Benin, a Tanzanian origin (Kokutse et al., 2009a) is used for reforestation since 1985, but does not show significant difference with the pre-existing material (Azankpan et al., 2009). In Togo, local and Tanzanian origins are used with more success, but results vary greatly depending on the planting area (Kokutse et al., 2009a; Tondjo et al., 2014). In 1992, the Togolese Forest and logging Development Agency (ODEF) imported a teak progeny from the Ivory Coast (clonal seed orchard of the Sangoue station). The improved quality of the tree shape and growth are noticeable, showing the possible gains through one single generation after selection.

The objective of this study is to select faster growing individuals within the teak populations identified in Togo and Benin, by taking into account the morphological criteria of the trunk (bole height, growth increment of the stem, trunk shape, the importance of branching), as well as the highest wood qualities (heartwood percentage and wood properties). It should be kept in mind that variation between the individual trees and the sites of plantation can occur (Kokutse, 2002; Kokutse et al., 2004, 2006, 2009a), depending on the soil and the climatic conditions (Adjonou et al., 2010).

\section{Materials and methods}

\section{Selection of sampled populations}

The study was conducted in 5 forest reserves in Togo and 3 in Benin (figure 1). The 5 forests in Togo are located in Tchorogo (TC), Avétonou (AV), Asrama (AS), Haho-Baloe $(\mathrm{HB})$, and Eto (ET) plantations, which were identified as the most productive forests for wood quality (Kokutse et al., 2004; Adjonou et al., 2010). Among them, Avétonou, Asrama, Haho-Baloe and Eto were established in Togo since early $20^{\text {th }}$ century, with seeds coming from Northern India (Logossa, 2006; Kokutse et al., 2009). The parcels planted from these seeds are referred as local sources. The Tchorogo forest was planted with the local provenance seed (TC), including a subplot named $\mathrm{PI}$, with genetic material coming from the clonal seed orchard of Sangoué (Sodefor).

Tchorogo forest (TC) reserve has a tropical guinean climate characterized by a relatively late arrival of rain in May and a gradually increase in rainfall till September. The average annual rainfall amounts to $1,400 \mathrm{~mm}$. The mean annual temperature is $26^{\circ} \mathrm{C}$. The soils are ferruginous, lateritic

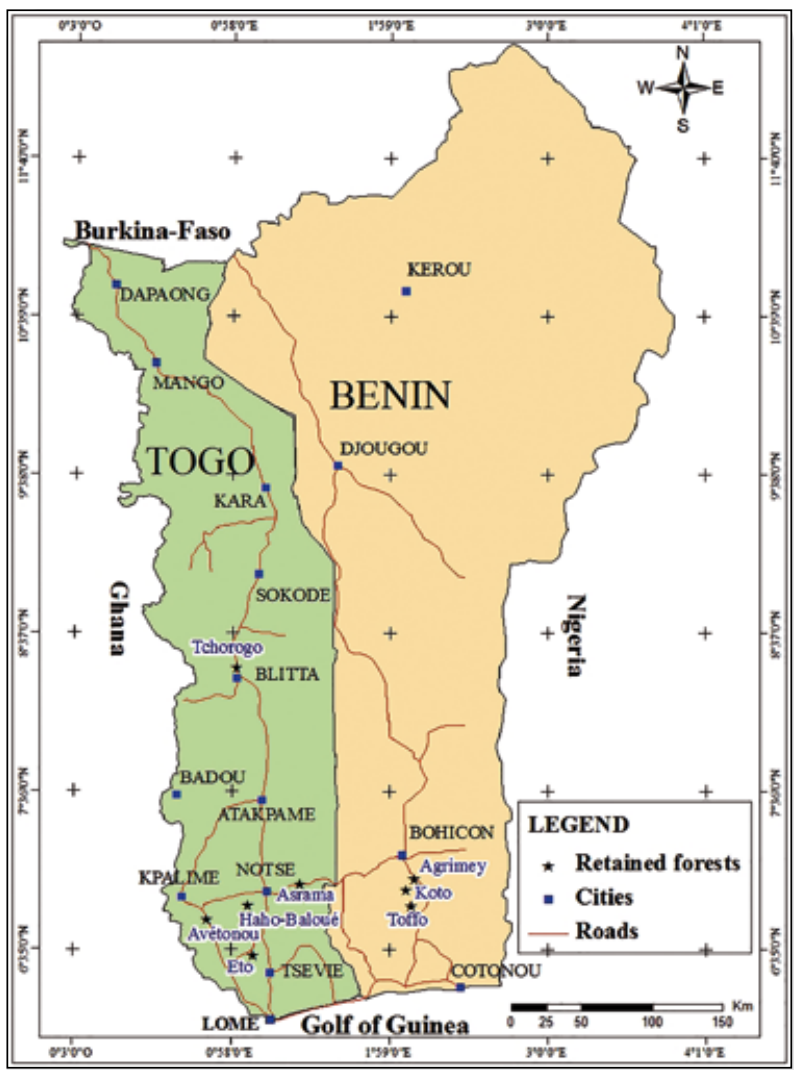

Figure 1.

Studied forests in the Republics of Togo and Benin. Black stars represent the geographical position of teak population from which Plus Trees originated. 
and waterlogged in places. Asrama forest (AS) has a Guinean-type climate with two dry seasons and two rainy seasons characterised by an interannual mean temperature between 26 and $27^{\circ} \mathrm{C}$, the annual rainfall is around $1,200 \mathrm{~mm}$. The soils are only slightly eroded, ferruginous and hydromorphic. The vegetation is dominated by teak plantations, gallery forests and crop fields. Avétonou forest (AV) has a Guinean-type climate with four seasons. Mean annual rainfall varies between 1,100 and $1,400 \mathrm{~mm}$ with a maximum in June. Average annual temperature varies between $29^{\circ} \mathrm{C}$ and $36^{\circ} \mathrm{C}$. Soils are ferruginous, leached, hardened and sometimes parched. Along river banks and in certain basin with periodical flooding, there are soils containing montmorillonite clays. In Eto forest (ET), the climate is the subequatorial type with four seasons including two rainy seasons and two dry seasons, with rainfall ranging between 1,000 and 1,200 mm approximately. The landscape offers a mosaic of savannahs and forests. Haho-Baloe forest (HB) is characterized by subequatorial climate with rainfall reaching $1,100 \mathrm{~mm} /$ year. Mean annual temperature is $25^{\circ} \mathrm{C}$. Soils are sandy clay. The natural vegetation consists of Guinean savannas.

In Benin, within teak plantations from the forests reserves of Lama, the forests of Koto, Toffo and Agrimey were selected among the forest managed by the National Wood Agency of Benin (ONAB). These forests were selected on their productivity indexes. The Agrimey plantations were established with the local seeds with unidentified origin, but some of them could come from Togo (Ganglo, 1999; Houayé, 1993). In the remaining forests of Benin some plantations are established with local seeds or with seeds collected in Tanzania (Azankpan et al., 2009). Toffo forest reserve is under the influence of a subequatorial climate with a long rainy season from March to July and a short rainy season from September to October. The long dry season extends from November to February and, the short dry one covers August. The mean annual rainfall is $1,030 \mathrm{~mm}$; the mean daily temperature is $27.5{ }^{\circ} \mathrm{C}$ while the relative humidity varies from 52 to $95 \%$. Annual rainfall in Koto and Agrimey forests is around $1,000 \mathrm{~mm} /$ year and temperature ranges between 22 and $35^{\circ} \mathrm{C}$. The predominant vegetation consist of semi-deciduous forests. Ganglo and De Foucault (2006) reffered to its soil as "Black cotton soils" or "vertisols"

\section{Plus Trees selection}

Within every forest, the Plus trees parcels were selected with the support of ODEF and ONAB officers. The criteria of selection included the plantation age and the good tree shape. The parcels were at least 15 -year-old, which is the minimum age required to confirm that the expression of the wood main technological properties (heartwood proportion, wood color, natural durability) is achieved for commercial purpose (Bruce, 1964; Bhat et al., 2001). Dendrometric characteristics of each selected parcel $(n=20$ in Togo and in Benin $n=8$ ) were determined by a random installation of two non-permanent plots of $20 \mathrm{~m} \times 20 \mathrm{~m}$. In these plots, dendrometric characteristics (the diameter at breast height, the total height, annual height and, annual circumference increments and the bole height) were measured for all trees,
In a first step, the selection of the Plus trees was performed based on the following morphological criteria: bole height (at least $10 \mathrm{~m}$ ) and trunk shape (straight, without grooves, bumps, epicormics buds, fluting, forks, large branches and no apparent parasites attacks). In addition, the trunk base should be cylindrical, without buttresses, and the crown well developed (photo 1 ). Inside the parcels, the selected trees must not be positioned at the edge of the plantation to avoid "edge effects". The trees selected according to these morphological criteria, ratified by at least 5 observers, are qualified as Candidate Plus trees (CPTs).

Then, in order to fine-tune this first selection, wood properties were taken into account: on each CPTs, $1.5 \mathrm{~cm}$ diameter wood core were sampled at breast height in order to estimate various wood properties. Heartwood percentage was calculated by measuring the distance from the stem pith to the heartwood-sapwood boundary and inner bark on each wood core (Kokutse et al., 2004). The color was measured every $10 \mathrm{~mm}$ along the longitudinal-radial surface of splitted cores using portable spectrophotometer (MICROLASH DATA COLOR) as described by Amusant et al. (2004). The reflectance data were collected at $10 \mathrm{~nm}$ intervals over the visible spectrum (from 400 to $700 \mathrm{~nm}$ ). The reflectance readings were converted into $L^{*}, a^{*}$ and $b^{*}$ values, where $L^{*}$ describes lightness along the lightness axis $(100=$ white or brightness; $0=$ black or darkness) of a colour, $a^{\star}$ value describes the redness ( $a^{\star}$ positive value), or greenness ( $a^{*}$ negative value). Yellowness-blueness is shown by value $b^{\star}$, with $b^{\star}$ positive for yellowness and $b^{\star}$ negative for blueness. The splitted remaining core was then cut into specimens (RTL dimensions $15 \times 7.5 \times 15 \mathrm{~mm}$ ) for basic density measurements. Basic density was calculated on the specimens by calculating the ratio between oven dry weights and saturated volume, as described by Tondjo et al. (2014). The evaluation of other properties, including natural durability, fibre saturation point (FSP), modulus of elasticity (MOE) and tangential and radial shrinkage, was done through previous predictive models based on near infrared spectroscopy (NIRS). These models have been based mainly on samples from Togo in partnership with CIRAD (Kokutse et al., 2010; Chaix et al., 2010, 2008; Tondjo et al., 2014). Before the basic density measurement, the reflectance data were collected at $15 \mathrm{~nm}$ intervals from 800 to 2,500 nm with Bruker Vector $22 \mathrm{~N}-1$ spectrophotometer. The spectral data were used to predict the value of each character. Individual tree value was based on the mean of specimens.

\section{Data Processing}

Annual increments in height, circumference, and volume were calculated for the 5 forests in Togo, for the Parcel of Ivorian origin in Tchorogo and for the 3 forests in Benin, using the dendrometric data of the plots (tree age, total height and circumference at $1.30 \mathrm{~m}$ height, volume (V) was calculated from the two others by using the following equation:

$V=\left(\left(\left(\pi \times(\mathrm{DBH} / 2)^{2} \times 1.3\right)+\left(\left(\pi \times(\mathrm{DBH} / 2)^{2} \times(\mathrm{H}-1.3)\right) / 3\right)\right) /\right.$ 100000) 
These data were measured on 569 trees in Togo (HahoBaloe $n=87$, Eto $n=116$, Asrama $n=99$, Avétonou $n=80$, local Tchorogo $n=162$, parcel of Ivorian origin in Tchorogo $n=25$ ) and 90 in Benin (Agrimey $n=26$, Toffo $n=22$, Koto $n=42$ ). The comparison of the dendrometric characteristics between parcels at forest level, and between forests was performed by a variance analysis using MINITAB software (values were considered statistically significant if $P<0.05$ ). For wood properties, the average values for trees were compared between forests by variance analysis. The multicriteria final selection of CPTs was based on all properties independently and confirmed by using a principal component analysis (PCA) which allowed us to show the CPTs by combining good performances for growth, bole form and wood quality.

\section{Results}

\section{Dendrometric information}

In Togo, the Annual Height Increment (AHI) ranged from $0.66 \mathrm{~m} /$ year, in the Tchorogo forest, to $1.67 \mathrm{~m} /$ year, in the Asrama forest (table I). Annual Circumference Increment (ACI) ranged from $2.5 \mathrm{~cm} /$ year in the Haho-Baloe forest to $4.0 \mathrm{~cm}$ / year in the Asrama forest. Considering these two parameters, the tree growth in the Asrama forest was significantly higher. However the parcel of Ivorian origin (PI) presented annual growth increase, expressed in terms of height $(\mathrm{AHI}=1.05 \mathrm{~m} /$ year $)$ and circumference $(\mathrm{ACl}=3.7 \mathrm{~cm} /$ year $)$, closed to those measured in the Asrama, but higher than the other Togolese forests. The parcel of Ivorian origin presented significantly the highest bole height $(\mathrm{BH}=15.1 \mathrm{~m}, \mathrm{P}<0.001)$ compared to other Togolese plantations established with the local seeds, for which the $\mathrm{BH}$ ranges from $9.7 \mathrm{~m}$ in Haho-Baloe to $12.6 \mathrm{~m}$ in the Avétonou forest (table I, figure 2). For Togolese teak, there was a significant tree effect at parcel level, considering the annual height increment $(\mathrm{AHI})$ and circumference $(\mathrm{ACl})$. For the Haho-Baloe plantations, the inter-tree variability within the parcels was about $20 \%$ higher for $\mathrm{AHI}(\mathrm{P}=0.017)$ and $29 \%$ for $\mathrm{ACl}(\mathrm{P}<0.001)$. For the boles heights, the inter-tree variation was also much higher with a coefficient of variation of $43 \%$ in Haho-Baloe forest. In Asrama forest, no significant effect was found between trees considering the $\mathrm{AHI}$, but its variability was $24 \%$. However $\mathrm{ACl}$ presented a tree significant effect $(P=0.01)$ with an inter-tree variability of about $25 \%$. In the Avétonou forest, there was also a significant tree effect for $\mathrm{ACl}, \mathrm{AHI}$ and $\mathrm{BH}(\mathrm{CV}=35 \%$ for $\mathrm{AHI}, 41 \%$ for $\mathrm{ACl}$, and $33 \%$ for $B H$ ). Similar results were obtained for the local teak population in Tchorogo for which the $\mathrm{CV}$ were respectively $37 \%$ for $\mathrm{AHI}, 32 \%$ for $\mathrm{ACl}$ and $31 \%$ for $\mathrm{BH}$. Inside the parcel of Ivorian origin (PI) in Tchorogo, the coefficients of variation at inter-tree level were lower than those found in the local teak populations (18\% for $\mathrm{AHI}, 25 \%$ for $\mathrm{ACl}$ and for $\mathrm{BH}$ ).

In Benin, the annual height increment ranged from $0.92 \mathrm{~m} /$ year in the Agrimey forest to $0.99 \mathrm{~m} /$ year in the Koto forest, and annual circumference increments varied from $3.5 \mathrm{~cm} /$ year in Agrimey forest to $4.2 \mathrm{~cm} /$ year to Toffo forest. The mean bole height was $10.3 \mathrm{~m}$ in Agrimey and $11.3 \mathrm{~m}$ in Koto (figure 2). The mean annual increment of trunk volume did not vary between the local seed plantations, those composed of mixed trees of the local seeds and from Tanzanian origin ones. However with the latter, height increment (AHI) was about $8 \%$ higher than the local provenance parcels, and the circumference increment $(\mathrm{ACl})$ was $20 \%$ higher. Within the plantations of Agrimey and Koto, the AHI and for $\mathrm{ACl}$ coefficients of variation at inter-tree level were approximately of $12 \%$, and $27 \%$ and $23 \%$ in Toffo forest. For the boles height, the CV values were $29 \%$ for populations of Toffo and Agrimey, and raised $40 \%$ in Koto.

The dendrometric criteria and bole form were used to select 67 CPTs in Togo and 18 in Benin. When all trees were considered together, regardless of forests and populations, the selected CPTs are those which presented the highest productivity $(\mathrm{AHI}$ and $\mathrm{ACl})$ at the parcels and population level (table I). The dendrometric performance of the selected CPTs is on average higher than the median performance of the population.

Table I.

Comparison between the growth characteristics of the Candidate Plus trees (CPTs) and the populations.

\begin{tabular}{|c|c|c|c|c|c|c|c|c|c|}
\hline & $\begin{array}{l}\text { Asrama } \\
\text { Togo }\end{array}$ & $\begin{array}{l}\text { Avétonou } \\
\text { Togo }\end{array}$ & $\begin{array}{l}\text { Eto } \\
\text { Togo }\end{array}$ & $\begin{array}{c}\text { Haho-Baloé } \\
\text { Togo }\end{array}$ & $\begin{array}{l}\text { Sites } \\
\text { Tchorogo } \\
\text { Togo }\end{array}$ & $\begin{array}{l}\text { IP } \\
\text { Togo }\end{array}$ & $\begin{array}{c}\text { Agrimey } \\
\text { Benin }\end{array}$ & $\begin{array}{l}\text { Koto } \\
\text { Benin }\end{array}$ & $\begin{array}{c}\text { Toffo } \\
\text { Benin }\end{array}$ \\
\hline $\begin{array}{l}\mathrm{ACl} \text { of CPTs (Mean } \\
\pm \text { Standard deviation) }\end{array}$ & $\begin{array}{c}5.10 \\
\pm 1.26\end{array}$ & $\begin{array}{r}3.62 \\
\pm 1.08\end{array}$ & $\begin{array}{c}3.87 \\
\pm 0.43\end{array}$ & $\begin{array}{l}3.52 \\
\pm 0.72\end{array}$ & $\begin{array}{c}3.11 \\
\pm 0.48\end{array}$ & $\begin{array}{c}5.07 \\
\pm 0.38\end{array}$ & $\begin{array}{c}4.31 \\
\pm 0.57\end{array}$ & $\begin{array}{r}4.90 \\
\pm 0.74\end{array}$ & $\begin{aligned} & 5.02 \\
\pm & 0.80\end{aligned}$ \\
\hline $\begin{array}{l}\mathrm{ACl} \text { (Median value } \\
\text { for the population) }\end{array}$ & 3.93 & 2.47 & 2.75 & 2.33 & 2.57 & 3.76 & 3.62 & 4.29 & 4.27 \\
\hline $\begin{array}{l}\text { AHI for CPTs (Mean } \\
\pm \text { Standard deviation) }\end{array}$ & $\begin{array}{c}1.29 \\
\pm 0.37\end{array}$ & $\begin{array}{c}0.81 \\
\pm 0.34\end{array}$ & $\begin{array}{c}0.89 \\
\pm 0.09\end{array}$ & $\begin{array}{c}0.94 \\
\pm 0.08\end{array}$ & $\begin{array}{c}0.66 \\
\pm 0.20\end{array}$ & $\begin{array}{c}1.26 \\
\pm 0.05\end{array}$ & $\begin{array}{r}1.04 \\
\pm 0.05\end{array}$ & $\begin{array}{c}1.09 \\
\pm 0.08\end{array}$ & $\begin{array}{r}1.08 \\
\pm 0.29\end{array}$ \\
\hline $\begin{array}{l}\text { AHI (Median value) } \\
\text { for the population }\end{array}$ & 1.20 & 0.67 & 0.8 & 0.84 & 0.61 & 1.05 & 0.96 & 1.00 & 0.97 \\
\hline
\end{tabular}

AHI: Annual Height Increment (m/year), ACl: Annual circumference increment (cm/year), IP: Ivorian provenance.. 


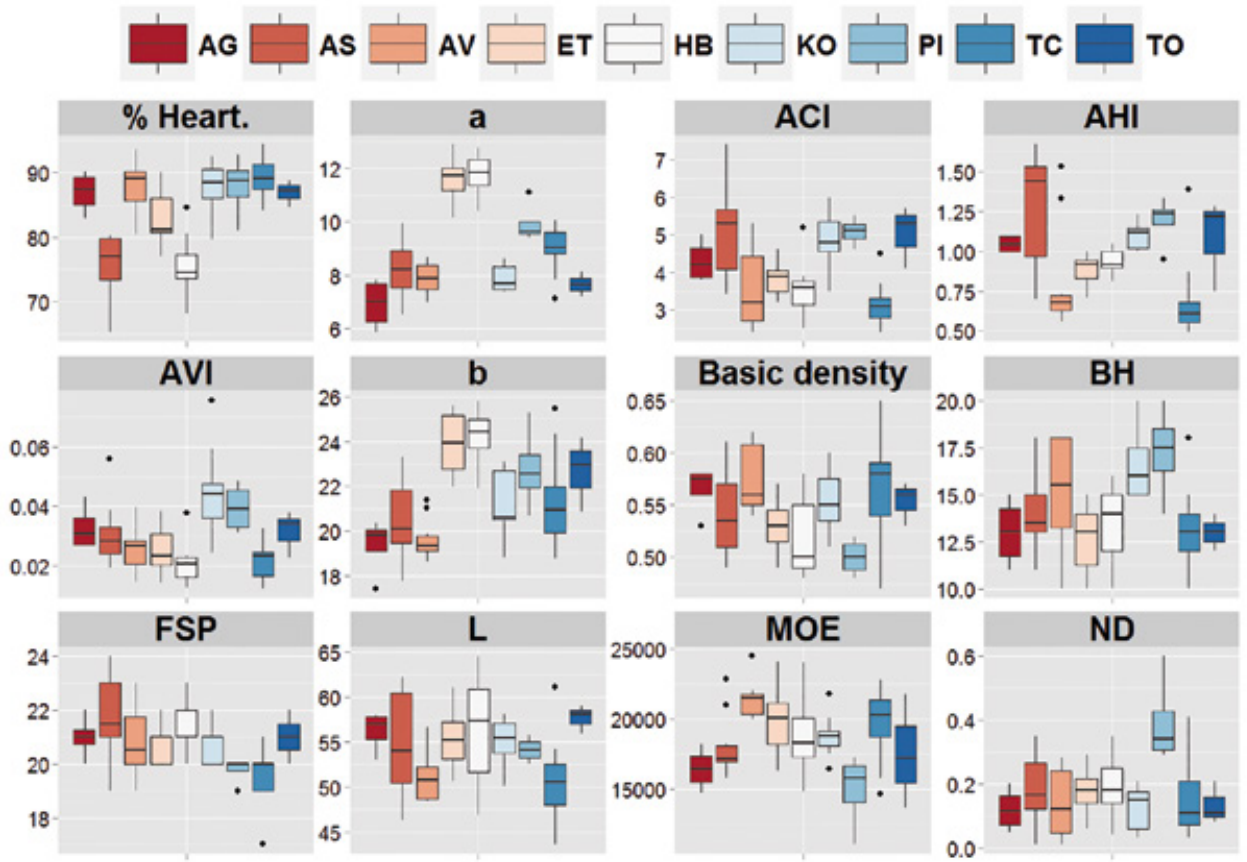

Figure 2.

Dendrometric characteristics and wood properties for Candidates Plus Tress of selected plantations in Benin and Togo. $\%$ Heart.: heartwood percentage, a: wood redness, ACl: Annual Circumference Increment (cm/year), AHI: Annual Height Increment (m/year), AVI: Annual Volume Increment ( $\mathrm{m}^{3} /$ year), b: wood yellowness-blueness, ND: Natural Durability of heartwood again fungus (\% relative mass loss), BH: Bole Height (m), L: Wood Lightness, MOE: Modulus of Elasticity (MPa), FSP: Fibre Saturation Point (\%), AS: Asrama forest, AV: Avétonou Forest, ET: Eto forest, HB: HahoBaloe forest, TC: Tchorogo forest, PI: Ivoirian origin parcel in Tchorogo, AG: Agrimey forest, TO: Toffo forest, KO: Koto.

\section{Percentage of volume of the heartwood}

The heartwood percentage of CPTs varied from $75.3 \%$ in Asrama to $89.7 \%$ for local teak in Tchorogo forest. Heartwood quantity in the Ivorian origin parcel (87.9\%) and in the populations of Avétonou (88.1\%) were comparable to the ones from local teak in Tchorogo (89.7\%). The Fisher's pairwise comparisons showed that CPTs from Asrama (75.3\%) and Haho-Baloe $(75.7 \%)$ presented significantly the lowest percentages of heartwood compared to the other forests. In Benin, the heartwood/sapwood ratio of the three forests sampled was very closed, with no significant variation (values ranges between $86.9 \%$ for Toffo and $87.8 \%$ for Koto) (table I, figure 2).

\section{Wood density and modulus of elasticity}

The mean wood density varied significantly with the CPTs origin (figure 2), for the Ivorian origin parcel and in Avétonou $\left(0.50 \mathrm{~g} / \mathrm{cm}^{3}\right.$ and $0.58 \mathrm{~g} / \mathrm{cm}^{3}$ respectively), with intermediate values for Haho-Baloe $\left(0.52 \mathrm{~g} / \mathrm{cm}^{3}\right)$, Eto forest $(0.53 \mathrm{~g} /$ $\left.\mathrm{cm}^{3}\right)$, Tchorogo $\left(0.57 \mathrm{~g} / \mathrm{cm}^{3}\right)$, and Asrama $\left(0.54 \mathrm{~g} / \mathrm{cm}^{3}\right)$. In Benin, the Agrimey forests CPTs showed a higher wood density $\left(0.58 \mathrm{~g} / \mathrm{cm}^{3}\right)$ than trees from Koto forest $\left(0.53 \mathrm{~g} / \mathrm{cm}^{3}\right)$ and Toffo $\left(0.54 \mathrm{~g} / \mathrm{cm}^{3}\right)$, but these values were not significantly different. Inside Togo populations, the wood density variability was lower, with variation coefficient ranging from $3 \%$ in CPTs for the Ivorian provenance parcel in Tchorogo, to $8 \%$ for the local teak populations in Tchorogo. In Benin, the variation observed for wood density in the forest of Koto and Agrimey was around $6 \%$ and increased to $11 \%$ in Toffo.

The modulus of elasticity (MOE) of Togo CPTs reached $21467 \mathrm{MPa}$ in Avétonou (table II), while the lowest values are found for Asrama trees (18,000 MPa). As for wood density, the CPTs from the Ivorian origin parcel presented a particularly low value of MOE (14,928 MPa), significantly different from the one observed in the local teak trees in Togo. In Benin, the MOE values ranges between 16,408 MPa (in Agrimey forest CPTs) and 18,783 MPa (Koto forest CPTs), with no significant differences between the local and the Tanzanian origin. While MOE and wood density increased with tree age, no significant correlation was found $\left(R^{2}=0.20\right.$; $P<0.001$ for wood density; $R^{2}=0.23 ; P<0.001$ for MOE).

\section{Fiber Saturation Points (FSP) and shrinkage}

The results obtained for the CPTs selected in the Ivorian origin parcel in Togo ranged from $19.7 \pm 0.2 \%, 3.6 \% \pm 0.3$ to $2.7 \pm 0.2 \%$ for the FSP, tangential and radial shrinkage respectively (table II). For the local teak in Togo, FSP ranged between $19.5 \pm 0.2 \%$ (in local CPTs in Tchorogo) and $20.6 \pm 0.6 \%$ (in Asrama trees). Shrinkages values ranged 
Table II.

Dendrometrics and wood properties performances of Plus Trees selected in Togo and Benin.

\begin{tabular}{|c|c|c|c|c|c|c|c|c|c|}
\hline $\begin{array}{l}\text { Plus } \\
\text { trees No }\end{array}$ & $\begin{array}{c}\text { Age } \\
\text { (years) }\end{array}$ & $\begin{array}{c}\text { AHI } \\
\text { (m/year) }\end{array}$ & BH (m) & $\begin{array}{c}\mathrm{ACl} \\
\text { (cm/year) }\end{array}$ & $\% B C$ & ND & FSP & $\begin{array}{c}\text { Basic density } \\
\left(\mathrm{g} / \mathrm{cm}^{3}\right)\end{array}$ & $L^{*}$ \\
\hline HB1 & 25.00 & 0.92 & 13.00 & 0.87 & 75.98 & 0.06 & 21.32 & 0.58 & 52.51 \\
\hline HB3 & 25.00 & 1.00 & 15.00 & 1.11 & 73.28 & 0.04 & 20.89 & 0.56 & 47.55 \\
\hline HB7 & 25.00 & 0.92 & 15.00 & 1.01 & 73.75 & 0.16 & 20.87 & 0.56 & 49.77 \\
\hline ET4 & 25.00 & 0.96 & 13.00 & 1.26 & 89.85 & 0.06 & 19.97 & 0.55 & 50.56 \\
\hline ET8 & 24.00 & 0.92 & 14.00 & 1.23 & 83.11 & 0.15 & 19.80 & 0.54 & 45.95 \\
\hline AV2 & 15.00 & 1.53 & 18.00 & 1.66 & 87.11 & 0.01 & 19.67 & 0.61 & 48.04 \\
\hline AV3 & 45.00 & 0.56 & 18.00 & 1.00 & 88.94 & 0.02 & 18.65 & 0.62 & 53.87 \\
\hline AV4 & 30.00 & 0.58 & 13.00 & 1.23 & 89.17 & 0.04 & 19.72 & 0.60 & 46.39 \\
\hline AV8 & 37.00 & 0.65 & 14.00 & 1.02 & 93.14 & 0.18 & 21.51 & 0.55 & 47.95 \\
\hline AS2 & 27.00 & 0.70 & 13.00 & 1.12 & 80.16 & 0.05 & 19.07 & 0.61 & 48.79 \\
\hline AS3 & 27.00 & 0.78 & 15.00 & 1.07 & 79.98 & 0.01 & 19.43 & 0.57 & 47.92 \\
\hline $\mathrm{Pl} 2$ & 21.00 & 1.24 & 18.00 & 1.47 & 92.75 & 0.37 & 19.86 & 0.49 & 43.59 \\
\hline TC2 & 38.00 & 0.68 & 14.00 & 1.05 & 93.47 & 0.03 & 18.77 & 0.65 & 50.70 \\
\hline TC5 & 37.00 & 0.59 & 11.00 & 0.99 & 86.34 & 0.08 & 19.36 & 0.60 & 50.59 \\
\hline TC6 & 37.00 & 0.62 & 10.00 & 1.00 & 91.33 & 0.11 & 19.57 & 0.58 & 53.57 \\
\hline TC7 & 37.00 & 0.49 & 10.00 & 0.78 & 88.26 & 0.09 & 19.09 & 0.58 & 50.05 \\
\hline TC8 & 38.00 & 0.66 & 13.00 & 0.95 & 91.66 & 0.10 & 18.82 & 0.56 & 57.07 \\
\hline TC9 & 38.00 & 0.68 & 13.00 & 0.93 & 90.94 & 0.14 & 18.65 & 0.56 & 50.05 \\
\hline TC10 & 38.00 & 0.50 & 13.00 & 0.95 & 94.44 & 0.07 & 18.83 & 0.59 & 58.08 \\
\hline TC11 & 36.00 & 0.50 & 12.00 & 1.00 & 91.66 & 0.07 & 18.61 & 0.57 & 55.87 \\
\hline TC12 & 36.00 & 0.56 & 12.00 & 1.05 & 84.16 & 0.07 & 18.60 & 0.60 & 53.02 \\
\hline TC13 & 36.00 & 0.58 & 15.00 & 0.95 & 88.36 & 0.05 & 19.96 & 0.64 & 56.19 \\
\hline TC14 & 36.00 & 0.53 & 12.00 & 0.88 & 87.43 & 0.07 & 17.21 & 0.60 & 52.51 \\
\hline TC17 & 36.00 & 0.72 & 13.00 & 1.10 & 90.88 & 0.16 & 19.76 & 0.59 & 47.55 \\
\hline TC22 & 31.00 & 0.87 & 18.00 & 1.14 & 91.51 & 0.21 & 19.81 & 0.54 & 49.77 \\
\hline $\mathrm{KO} 2$ & 22.00 & 1.14 & 20.00 & 5.23 & 88.53 & 0.15 & 21.37 & 0.59 & 50.56 \\
\hline KO4 & 22.00 & 1.23 & 18.00 & 5.23 & 90.61 & 0.03 & 20.02 & 0.60 & 45.95 \\
\hline K06 & 25.00 & 1.16 & 20 & 6.00 & 90.37 & 0.10 & 20.94 & 0.56 & 48.04 \\
\hline K07 & 25.00 & 1.12 & 18 & 3.48 & 90.61 & 0.04 & 19.74 & 0.57 & 53.87 \\
\hline T01 & 24.00 & 0.75 & 13 & 4.13 & 87.31 & 0.11 & 19.95 & 0.57 & 46.39 \\
\hline TO2 & 18.00 & 1.22 & 14 & 5.67 & 84.60 & 0.08 & 20.76 & 0.56 & 47.95 \\
\hline AG1 & 25.00 & 1.00 & 14 & 3.84 & 90.18 & 0.15 & 22.04 & 0.57 & 48.79 \\
\hline AG2 & 25.00 & 1.00 & 15 & 3.86 & 88.93 & 0.05 & 20.61 & 0.58 & 47.92 \\
\hline
\end{tabular}

AHI: Annual Height Increment (m/year), ACI: Annual circumference increment (cm/year), BH: bole height (m), \%BC: Percentage of heartwood, FSP: fibre saturation point, ND: natural durability (express in mean mass loss), L*: wood lightness, AS: Asrama forest ( $n=2$ Plus Trees), AV: Avétonou forest ( $n=4$ Plus Trees), ET: Eto forest ( $n=2$ Plus Trees), HB: Haho-Baloe forest ( $n=3$ Plus Trees), TC: Tchorogo forest ( $n=13$ Plus Trees), PI: Ivoirian origin parcel in Tchorogo ( $n=1$ Plus Tree), AG: Agrimey forest ( $n=2$ Plus Trees), KO: Koto forest ( $n=4$ Plus Trees), TO: Toffo forest ( $n=2$ Plus Trees).

from $2.9 \pm 0.1 \%$ (in Eto) to $3.9 \pm 0.1 \%$ (in Avétonou) for the radial shrinkage, and from $4.71 \pm 0.2 \%$ (in Eto) to $6.6 \pm 0.2 \%$ (Avétonou) for tangential shrinkage (figure 2). Regardless of FSP and wood shrinkage characters, CPTs from the Ivorian origin parcel are significantly different from trees selected in the local teak populations in Togo.
In Benin, the selected CPTs were very similar considering the wood FSP (table II). The FSP values varied from $20.6 \pm 0.2 \%$ to $21.0 \pm 0.4 \%$ (in Koto and Agrimey forest respectively) from $2.9 \pm 0.3 \%$ to $3.0 \pm 0.1 \%$ (in Toffo and Koto forest respectively) for radial shrinkage, and from $4.8 \pm 0.2 \%$ to $5.0 \pm 0.1 \%$ (in Agrimey to Koto forest respectively) for 
tangential shrinkage. When all CPTs were considered together, no significant effect of tree age was found in FSP and shrinkage $\left(R^{2}=0.34\right.$ and $P<0.001$ for the FSP; $R^{2}=0.27$ and $P<0.001$ for radial shrinkage, $R^{2}=0.07$ and $P=0.008$ for tangential shrinkage).

\section{Natural durability against decay and wood color}

The average mass losses obtained were very low in all selected CPTs (between $0.1 \pm 0.03 \%$ and $0.2 \pm 0.03 \%$ in Avétonou and Haho-Baloe forest respectively). Significant differences were observed in mass losses considering CPTs origin $(P=0.002)$. However the influence of tree age on wood durability was not significant $\left(R^{2}=0.07 ; P=0.007\right)$. Wood samples from the Ivorian origin CPTs (with \%mass loss of $0.39 \pm 0.07 \%$ ) are less resistant to pathogen attack than wood from local teak in Togo. In Benin, the CPTs mass losses were approximately of $0.12 \pm 0.02 \%$ for the 3 forests.
In Togo, the lightness $\left(L^{\star}\right)$ of the wood samples was lower than in the CPTs from Tchorogo $\left(L^{*}=50.5 \pm 0.8\right)$ and Avétonou forests $\left(L^{\star}=51.1 \pm 0.9\right)$. The average values differed significantly $(P=0.003)$ between the populations. When considering all the CPTs, the regression analysis showed that tree age did not influence significantly their lightness $\left(y=63.20-0.35\right.$ * âge, $R^{2}=0.33$ and $\left.P<0.000\right)$. However, there was a significant inter-tree effect within the population. Inter-tree variability was about $10 \%$ in the population of Eto and extends to 15\% in the forest of Asrama in Togo. In Benin, the CPTs lightness ranged from $55.4 \pm 0.4$ in Koto forest to $57.6 \pm 0.7$ in Toffo forest (figure 4). The intertree variability within plantations was about $6 \%$ in Toffo, $8 \%$ in Koto and 13\% in Agrimey forest.

In the Togo populations, the redness or greenness values $\left(a^{\star}\right)$ ranged approximately from $8.07 \pm 0.11$ in the forest of Avétonou to $11.72 \pm 0.12$ in Haho-Baloe forest. In Benin, $a^{\star}$ values were between $6.92 \pm 0.95$ in Agrimey forest and
A

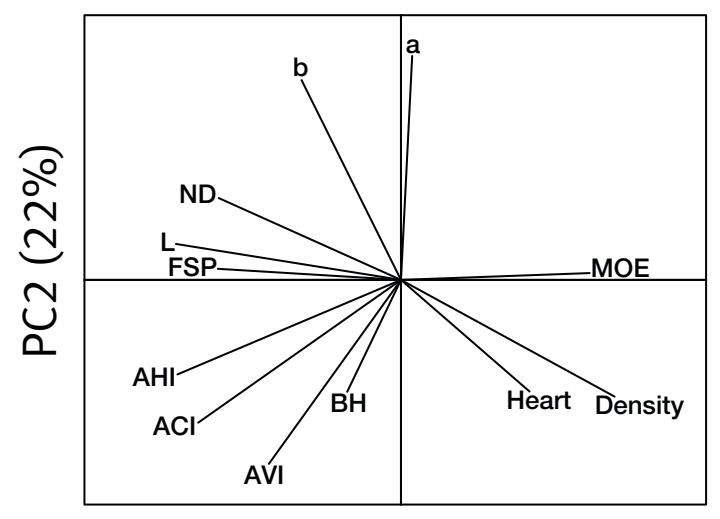

C

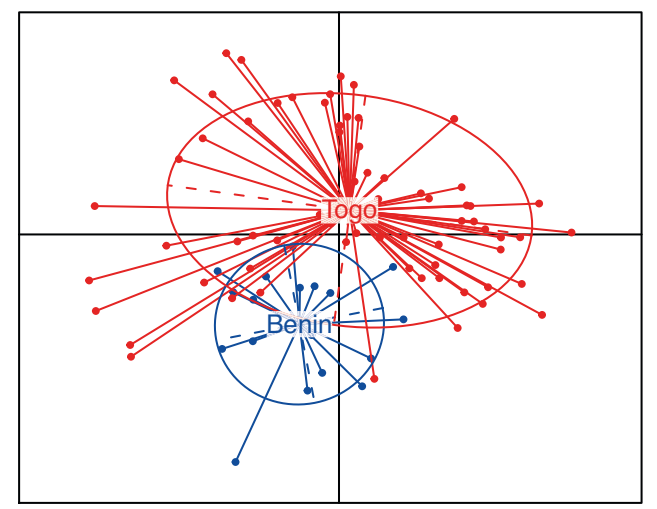

B

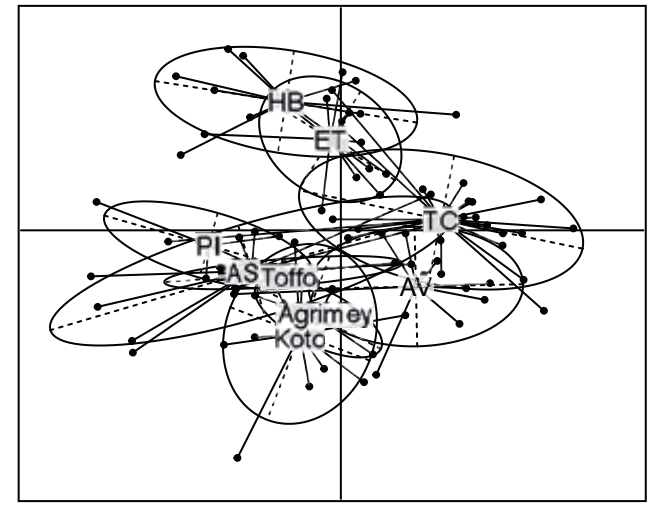

D

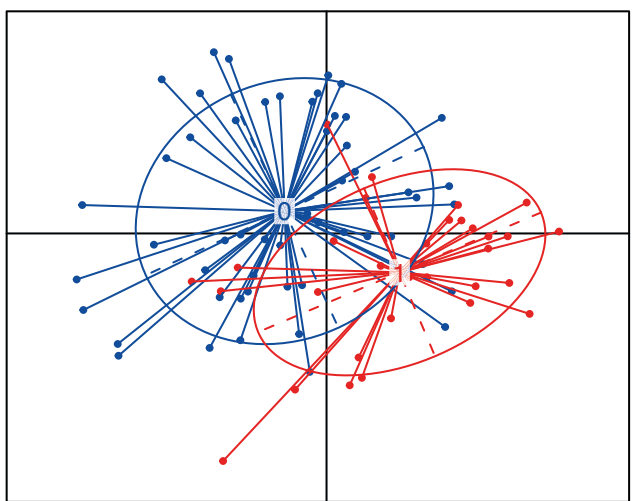

Figure 3.

Results of principal component analysis based on growth and wood properties off trees from Togo and Benin. A: Circle of correlations on the plan defined by components 1 and 2, B: distribution of candidates Plus trees on the PC1/PC2 plan according to the plantation, C: distribution of candidates Plus trees on the PC1/PC2 plan according to the country, D: distribution of candidates Plus trees on the PC1/PC2 plan according to the selection status. $1=$ selected tree, $0=$ non selected, AS: Asrama forest, AV: Avétonou forest, ET: Eto forest, HB: Haho-Baloe forest, TC: Tchorogo forest, PI: Ivoirian provenance parcel in Tchorogo, AHI: annual height increment (m/year), $\mathrm{ACl}$ : annual circumference increment (cm/year), AVI: Annual volume increment ( $\mathrm{m}^{3} /$ year), BH: Bole height (m), Heart: Heartwood percentage (\%), MOE: modulus of elasticity (MPa), FSP: Fiber saturation point (\%), ND: Natural durability (relative mass loss), L, a, b: Heartwood color parameters. 
$7.87 \pm 0.49$ in Koto. The parameter $a^{*}$ was not influenced by the age of the CPTs $\left(R^{2}=0.0\right.$ and $\left.P=0.9\right)$, but differed significantly depending on the plantations $(P<0.001)$. The CPTs from Haho-Baloe and Eto were significantly different and redder, while the CPTs from Togo Avétonou forest and from Koto, Agrimey and Toffo Benin forests are less red (figure 2). Within the populations, $a^{*}$ parameter varied from $13 \%$ in Asrama and Agrimey, to $6 \%$ in the other plantations.

\section{Multi-criteria selection of CPTs}

The two main axes of the principal components analysis, based on growth and wood properties, accounted for $59 \%$ of the total variability of dendrometric and technological performances of CPTs (figure 3). The results showed the distribution of CPTs, on the plan defined by components 1 and 2, according to the plantation, the country localization and their selection status. Axis 1 (37\% of the explained variability) opposed the wood density, the modulus of elasticity (MOE) and the percentage of heartwood (Heart) on one hand, and the Fibre Saturation Point (FSP), the heartwood color parameters $L^{*}$, the natural durability (ND), and the growth criteria (Annual Height Increment $\mathrm{AHI}$ and Annual Circumference Increment $\mathrm{ACl}$ ) on the other hand. Axis 2 of the PCA (22\% of the explained variability) opposes the $a^{*}$ and $b^{*}$ (yellowness-blueness) parameters (heartwood color parameters) to the stem volume increment ( $\mathrm{AVI})$ and the bole height $(\mathrm{BH})$. Therefore, the distribution of the trees on PC1 and PC2 plan allowed to confirm the efficiency of Plus Trees selection (25 trees in Togo and 8 in Benin, table II) and compare performances according to the classified groups (forest, country, selected or not).

The distribution of the CPTs scores in the plan formed by PC1 and PC2, allowed to discriminate the trees of Togo from those of Benin (figure $3 \mathrm{C}$ ), the latter presenting the highest increment of stem volume. Figure 3B distinguishes the categories of teak populations in Togo and Benin (Haho-Baloe HB, Asrama AS, Eto ET; Avétonou AV, Tchorogo TC; Toffo, Agrimey; Tchorogo plantations of Ivoirian origin PI; Koto). However, the inter-tree variability within the forest was relatively strong for Tchorogo, Asrama, Avetonou, Haho-Baloe. It was lower for Agrimey, Toffo, Tchorogo plantations of Ivoirian origin PI and Eto. The Avétonou and Tchorogo tree populations constitute a homogenous group with the highest wood density and heartwood percentage values. The Tchorogo plantations of Ivorian origin (PI) differ from others, based on their lower natural durability, while trees from Koto exhibited higher growth characteristics. The CPTs

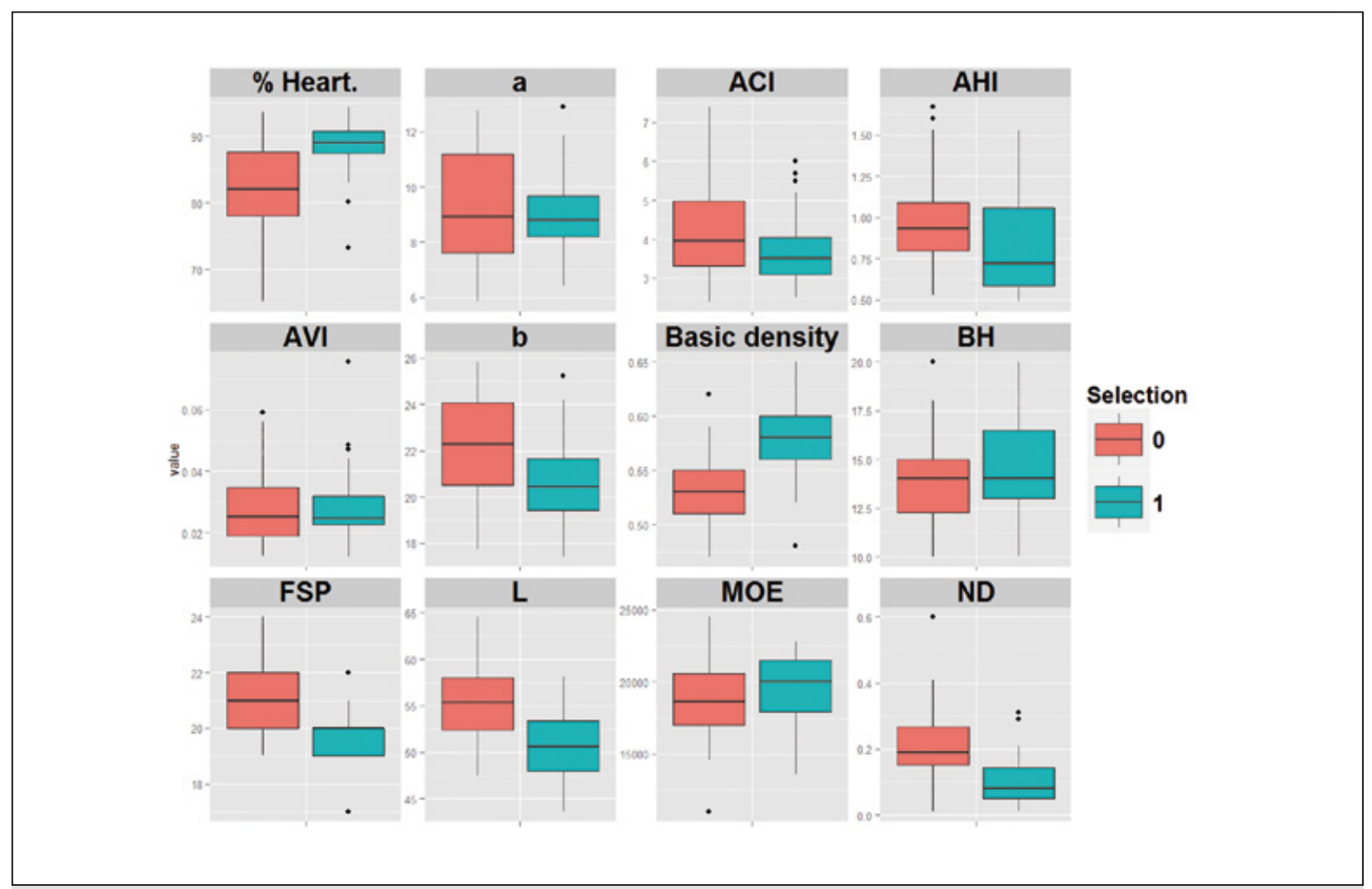

Figure 4.

Comparison of teak growth and wood properties between selected and non-selected trees in Togo and Benin. $1=$ selected tree, $0=$ non selected.

(\% Heart.: heartwood percentage (\%), $\mathrm{AHI}$ : annual height increment (m/year), $\mathrm{ACl}$ : annual circumference increment (cm/year), AVI: annual volume increment ( $\mathrm{m}^{3} /$ year), Basic density $\left(\mathrm{g} / \mathrm{cm}^{3}\right), \mathrm{BH}$ : Bole height $(\mathrm{m}), \mathrm{MOE}$ : modulus of elasticity (MPa), FSP: fiber saturation point (\%), ND: natural durability of heartwood (relative mass loss), L, a, b: heartwood color parameters. 
of Haho-Baloe and Eto combined simultaneously lower natural durability and MOE, lower percentage of heartwood and wood density, and higher value of FSP. Considering the trees distribution in the same plan, we highlighted average higher values for wood density, percentage of heartwood, natural durability and dimensional stability (low values of FSP) for Plus Trees (selected trees after the multi-criteria selection). The selected trees also presented in average higher performances for stem volume increment (AVI). The figure 4, comparing the performances of selected and not selected trees, highlights the superiority of the selected trees for all wood properties compared to the non-selected trees. For growth performances, selected trees had slightly lower values for $\mathrm{AHI}$ and, $\mathrm{ACl}$, or similar $\mathrm{AVI}$ values, and higher fork height values (Bole height), compared to non-selected trees.

\section{Discussion}

Higher growth performances of selected CPTs both in Togo and Benin are a combination of a better adaptation to the environmental conditions and favorable genotype-environment interactions (Kjaer and Foster, 1996). Considering the form of the trunks specifically, the impact of frequent bush fires in the Sub-Saharan Africa on their individual adaptation was important. In the two countries concerned by the current study, fires are one of the problems hindering the normal development of teak plantations. Therefore, teak trees from this region often present defects like marked fluting present along the stem, and important dents which greatly reduce the sawing yield (Louppe, 2008). The lower fork, related to early flowering, also decreases the volume of commercial bole. Consequently, the selected Plus Trees were identified as the most efficient in terms of trunk' shape (no grooves, no forks, and no bumps boss).

Regarding the dendrometric characteristics, the results of this study showed that the growth performance of the different populations (CPTs), based on the stem volume increment (annual circumference and height increments), was highly variable within and between populations. In Togo, the Asrama populations and the Ivorian provenance presented the most vigorous trees. The observed variability between the populations could be probably explained by the influence of genotype $x$ environment interaction (Matheson and Raymond, 1984). This interaction was not taken into account during the phenotypic selection of the CPTs in Togo. However, the high variability observed between individuals at intra-population level was the criteria for the phenotypic selection. Therefore, the selected trees were not the highest productive in all forests but they were most efficient at the parcel and at population levels. In Benin, the variability between populations (local and Tanzanian origins) is less marked, probably because all the Beninese plantations, selected in this study, are located in the Lama area characterized by similar ecological conditions and relatively homogeneous rainfall regime (Azakpan et al., 2009). Previous studies in Benin on these two Teak provenances have demonstrated that they did not present significant differences in terms of height and diameter annual increment (Ganglo and Maître, 2003; Azakpan et al.,
2009). However, these studies showed that the percentage of Tanzanian origin trees that flowered was significantly lower. This can be a good selection criterion to improve the tree height. Trees from the Ivorian provenance presented the highest bole height among the Togo and Benin populations. This might be linked to the late and scarce flowering observed in this origin, since the selection performed in Ivory Coast was based on the bole height. Indeed, several studies have shown the influence of the flowering age on teak stem height (Houayé, 1993; Callister, 2013; Tondjo et al., 2014; Flórez et al., 2014). During the investigations on the Tchorogo site, we observed that the quantities of seeds produced within the parcel of Ivorian origin were lower than in the local teak parcels.

Unlike other selections in West Africa breeding programs (including Ivory Coast), the wood quality for commercial purpose was taken into account to choose the Plus trees. This was made possible thanks to the progress realized in non-destructive analysis of the wood samples (Goh et al., 2007). Indeed several studies showed the need to integrate information from anatomical characteristics and properties in teak improvement programs (Thulasidas and Bhat, 2012; Hidayati et al., 2013, 2014). In this study, some intrinsic quality of wood specimens, especially the basic density and wood color, were directly determined through conventional standardized tests. Other features such as the natural durability, MOE and sorption properties were determined by indirect method using the prediction models developed for teak samples from Togo by using Near Infrared Spectrometry (Tondjo et al., 2014; Kokutse et al., 2010; Chaix et al., 2008, 2010). Nevertheless, these authors pointed out that the accuracy of the developed models is slightly lower compared to reference measurement. However, this method provides unquestionable advantages because it allows the measurement of wood teak technological properties on a limited number of samples without damaging the trees. We showed that the basic density, which is the most important characteristic of the CPTs mechanical performance, is significantly higher in local populations of Tchorogo and Avétonou in Togo. These two genetic materials are probably of different origin compared to the other local teak in Togo. Indeed the studies of Logossa (2006) on the genetic diversity of six teak populations from Togo (without including Tchorogo populations), showed a higher genetic distance between the populations of Avétonou compared to others. The performed multi criterion selection confirmed the homogeneity and the superiority of the local teak populations from Tchorogo and Avétonou, compared to other local teak in Togo, as these two populations also contained the highest percentages of heartwood (Kokutse et al., 2004). That is why, by using multi criteria analysis, we succeeded to select more Plus Trees in these two populations.

Results showed that trees' age influence very weakly the wood technological characteristics. Therefore, it suggests that selecting candidates with minimum age of 15 years in the parcels is perfectly appropriate to ensure a non-significant age effect on the wood properties. Indeed, the teak xylem maturation process begins approximately at the age of 15-25 years, which corresponds to the development of 
the adult wood by the cambium (Bhat et al., 2001; Kokutse et al., 2004). Therefore the main technological characteristics of the species are stable from this age. In addition, several authors reported that the dimensions of the main anatomical characteristics of teak (length, fiber wall width and thickness, and vessel diameter) gradually increases and stabilizes around 15-20 years (Bhat et al., 2001; Kokutse et al., 2009b; Hidayati et al., 2014). Hidayati et al. (2014) also reported that the basic density and some wood mechanical and anatomical characteristics are genetically controlled in teak. These results confirmed the high importance of wood properties and tree shape in the efficiency of multi criteria selection we have used. Thus, the improvement program started from Plus Trees selection will produce improved clonal plants deployed by vegetative propagation for a future reforestation in Togo and Benin.

\section{Conclusion}

This study enables to determine the main performances of teak in different forests reserves in Togo and Benin. In Togolese forest, inter-tree variability within local populations is strong when combining growth and wood characteristics. However this variability is lower for Agrimey and Toffo populations in Benin. Based on these variabilities, 25 Plus Trees were selected in Togo and 8 in Benin populations. These trees constitute high performing trees in terms of morphological characteristics and wood properties. The next step will be the multiplication of these 25 Plustrees. Improved performance of plantations will be secured by these new genetic resources for the reforestation activities in Togo and Benin.

\section{Acknowledgements}

The authors thank ODEF (Office de Développement et d'Exploitation des Forêts du Togo) and ONAB (Office National du Bois du Bénin) for the technical supports, and Cirad for the financial support (Togo-Brazil travel for Prof. Kokutse). This work has been carried out in the framework of the AUF West Africa Program (Stimulation et valorisation de la recherche) and is a part of Akpenè Afiwa Dzigbodi's Ph.D thesis (grant from the International Foundation For Sciences IFS and the International Tropical Timber Organization ITTO and Cirad grant).

\section{Bibliographical references}

Adjonou K., Kokutse A. D., Kokou K., Ganglo J., De Foucault B., 2010. Environmental and wood biophysical variabilities in teak plantations in Togo (West Africa). Acta Botanica Gallica, 157 (3): 387-399.

Amusant N., Beauchêne J., Fournier M., Janin G., Thévenon M., 2004. Decay resistance in Dicorynia guianensis Amsh: Analysis of inter-tree and intra-tree variability and relations with wood colour. Annals of Forest Science, 61: 373-380.

Azankpan J. D., Ganglo J. C., Zohoun S., 2009. Performance de deux provenances de teck (Tectona grandis L.F). Annales des Sciences Agronomiques, 12: 55-65.

Bhat K. M., Priya P. B., Rugmini P., 2001. Characterisation of juvenile wood in teak. Wood Science and Technology, 34: 517-532.

Béhaghel I., 1999. État des plantations de teck (Tectona grandis) dans le monde. Bois et Forêts des Tropiques, 262: 5-18. http://bft.cirad.fr/cd/BFT 262 6-18.pdf

Bruce J. Z., 1964. Amélioration des arbres forestiers pour les qualités du bois. Consultation FAO/IUFRO sur la génétique forestière. Revue internationale des forêts et des produits forestiers, $18: 2-3$.

Callister A. N., 2013. Genetics parameters and correlations between stem size, forking, and flowering in teak (Tectona grandis). NRC, Research Press, 43: 1145-1150.

Chaix G., Monteuuis O., Goh D. K. S., Kokutse A. D., Derkyi N. S. A., Kadio A. A., et al., 2008. Rapid prediction of teak wood natural durability using near-infrared spectroscopy. In: Bhat K. M. (ed.), Balasundaran M. (ed.), Bhat K. V. (ed.), Muralidharan E. M. (ed.), Thulasidas P. K. (ed.). Processing and marketing of teak wood products of planted forests: Proceedings of the Regional Workshop held during 25-28 September 2007, Kerala Forest Research Institute, Peechi, India. Peechi, KFRI, 264-266.

Chaix G., Kokutse A. D., Ratovomboahangy B., Guibal D., Randrianjaf H., Rakotondraoelin H., et al., 2010. Prediction of radial, tangential shrinkages by NIRS for 2 tropical species Tectona grandis from Togo and Liquidambar styraciflua from Madagascar. Cerne, 16: 66-73.

Datta S. K., Kuma A., 1987. Histochemical studies of the transition from sapwood to heartwood in Tectona grandis. IAWA Bulletin, 8: 363-368.

Flórez J. B., Trugilho P. F., Lima J. T., Hein R. G. P., Da Silva J. R. M., 2014. Caracterización de la madera joven de Tectona grandis $L$. f. plantada en Brasil. Madera y Bosques, 20 (1): 11-20.

Ganglo J. C., 1999. Phytosociologie de la végétation naturelle de sous-bois, écologie et productivité des plantations de teck (Tectona grandis L. f.) du Sud et du Centre Bénin. Thèse de Doctorat, Université Libre de Bruxelles, Section Interfacultaire d'Agronomie, Laboratoire de Botanique, Systématique et de Phytosociologie, 391 p.

Ganglo J. C., Lejoly J., Pipar T., 1999. Le teck au Bénin, gestion et perspectives. Bois et Forêts des Tropiques, 261 (3): 17-27. http://bft.cirad.fr/cd/BFT 261 17-27.pdf 
Ganglo J. C., Maître H. F, 2003. État de la recherche forestière au Bénin - Bilan et Perspectives. Proceedings of the XII Word Forestry Congress. http://www.fao.org/docrep/ARTICLE/ WFC/XII/0188-C4.HTM

Ganglo J. C., de Foucault B., 2006. Plant communities, forest site identification and classification in Toffo reserve, SouthBenin. Bois et Forêts des Tropiques, 288 (2): 25-38. http:// bft.cirad.fr/cd/BFT 288 25-38.pdf

Goh D., Chaix G., Baillères H.,, Monteuuis O., 2007. Mass production and quality control of teak clones for tropical plantations: the Yayasan Sabah Group and CIRAD Joint Project as a case study. Bois et Forêts des Tropiques, 293 (3): 65-77. http://bft.cirad.fr/cd/BFT 293 65-77.pdf

Hidayati F., Ishiguri F., Lizuka K., Makino K., Tanabe J., Marsoem S. N., Na'iem M., etal., 2013. Growth characteristics, stress-wave velocity, and Pilodyn penetration of 15 clones of 12-year-old Tectona grandis trees planted at two different sites in Indonesia. Journal of Wood Sciences, 59 (3): 249 254.

Hidayati F., Ishiguri F., Lizuka K., Makino K., Marsoem S. N., Yokota S., 2014. Among-Clone variations of anatomical characteristics and wood properties in Tectona grandis planted in Indonesia. Wood and Fiber Science, 46 (3): 1-9.

Higuchi T., 1997. Biochemistry and molecular biology of wood. Springer, Berlin.

Houayé P., 1993. Étude de la variabilité des peuplements du teck au Bénin. Thèse de Docteur en sciences forestières à l'Université Georg-August Göttingen, 170 p.

Kjær E. D., Foster G. S., 1996. The Economics of Tree Improvement of Teak (Tectona grandis L.f). Danida, Forest Seed Centre Technical Note, (43): 1-27.

Kokutse K., Brancheriau L., Chaix G., 2010. Rapid prediction of shrinkage and fibre saturation point on teak (Tectona grandis L.f) wood based on near-infrared spectroscopy. Annals of Forest Science, 67: 403-412.

Kokutse A. D., Stokes A., Baillères H., Kokou K., Baudasse C., 2006. Decay resistance of Togolese teak (Tectona grandis L.f) heartwood and relationship with colour. Trees, 20: 219223.

Kokutse A. D., K., Adjonou K., Kokou K., Gbéassor M., 2009a. Problématique de la performance du teck de provenance tanzanienne par rapport au teck local en plantation au Togo. Bois et Forêts des Tropiques, 302 (4) : 43-52. http://bft. cirad.fr/cd/BFT 302 43-52.pdf

Kokutse A. D., Adjonou K., Kokou K., 2009b. Relationship between ecological indicators and teak wood characteristics in Tchorogo plantation (Togo). International Journal of Biological and Chemical Sciences, 3 (3): 483-491.

Kokutse A. D., Baillères H., Stokes A., Kokou K., 2004. Proportion and quality of heartwood in Togolese teak (Tectona grandis L.f.). Forest Ecology and Management, 189 (1): 37-48.

Kokutse A. D., 2002. Analyse de la qualité du bois de teck (Tectona grandis L.f) en plantation au Togo : formation de bois de cœur, propriétés mécaniques et durabilité. Thèse de doctorat de l'Université de Bordeaux I, 133 p. + annexes.
Logossa Z. T. 2006. Caractérisation génétique des Tecks (Tectona grandis L.f) provenant des plantations du Togo. Mémoire de Master II, Sciences du Bois et Fibres, Université de Bordeaux 1, 29 p.

Louppe D., 2008. Tectona grandis (L.f). In: Louppe D., Oteng-Amoako A. A. \& Brink M. (eds). Ressources végétales de l'Afrique tropicale. Bois d'oeuvre 1. [Translation of : Plant Resources of Tropical Africa 7 (1). Timbers 1. 2008]. Wageningen, Pays-Bas, Fondation Prota, Backhuys Publishers, Cta, $785 \mathrm{p}$.

Matheson A. C., Raymond C. A., 1984. The impact of Genotype $x$ Environment Interactions on Australian Pinus radiata breeding programs. Australian Forest Research, 14: $11-25$

MERF/FAO, 2011. Plan d'Action Forestier National du Togophase 1 (PAFN1-Togo 2011-2019). Projet TCP/TOG/3203(D), Lomé, Togo, $141 \mathrm{p}$.

Monteuuis O., Maître H.-F., 2007. New developments in teak cloning lead to better plantation stock. ITTO Tropical Forest Update, 17 (3): 13-15.

Moya R., Bond B., Quesada-Pineda H., 2014. A review of heartwood properties of Tectona grandis trees from fastgrowth plantations. Wood Science and Technology, 48 (2): 411-433.

Moya R., Alvarado-Calvo J., 2012. Variation of wood color parameters of Tectona grandis and its relationship with physical environmental factors. Annals of Forest Science, 69 (8): 947-959.

Thulasidas P. K., Bhat K. M., 2012. Mechanical properties and wood structure characteristics of 35-year old homegarden teak from wet and dry localities of Kerala, India in comparison with plantation teak. Journal of the Indian Academy of Wood Science, 9 (1): 23-32.

Tondjo T., Brancheriau L., Sabatier S.A., Kokutse A. D., Akossou A., Kouami K., Fourcaud T., 2014. Is the variability of key wood properties linked with the variability of key architectural traits? Case of planted Teak in Togo regarding thinning and provenance. Annals of Forest Science, 72 (6): 717-729. 